\title{
ЛIТАРАТУРАЗНАั̆СТВА
}

\author{
Ванда Cyna \\ Белосток

\section{«Исторические» детективы Владимира Короткевича: вчера и сегодня}

В эпоху экспансии массовой культуры стоит обратить внимание на произведения основоположника исторически-детективной романистики в современной белорусской литературе, в первую очередь на дебютантскую повесть В. Короткевича «Дикая охота короля Стаха» («Дзікае паляванне караля Стаха", 1950, 1954, публикация 1960) и на его менее удачный ${ }^{1}$, чем названная повесть, последний роман «Черный замок Ольшанский» («Чорны замак Альшанскі”, 1983).

Рассуждения о содержательной и художественной специфике детективов начнем с замечания, что эпитет «исторические» трудно признать вполне адекватным. Действие «любимой в народе» «Дикой охоты...» происходит в 80-е годы XIX столетия, а детективная интрига имеет корни в далеком прошлом, в начале XVII века, но исторические константы, такие как реальные факты, события, политически-экономические условия жизни, колорит эпох, трактуются автором весьма свободно и все эти элементы подчинены авторскому концепту прошлого и авторской иерархии ценностей, в которой самое важное место занимает идея формирования белорусского национального самосознания и самоопределения этого народа. В «Черном замке...» с прошлым связана только небольшая часть повествования и исторические факты трактуются тут еще более свободно, чем в повести.

1 Б. Невский, Современная готическая литература, «Мир фантастики» 2004, № 12, [online], http://community.live/journal.com/lit_gothig2184.htm, [дата доступа: 01.10.2009]. 
Каждый из детективов Короткевича содержит акценты полемики не только с навязанным советским писателям мировоззрением, но в еще большей мере с обязывающей всех публикующих в СССР нормативной поэтикой социалистического реализма. Попытки обойти запреты и указы, а также поиски новых художественных решений в данном случае дали довольно интересный результат близости к рождающейся тогда на Западе поэтике постмодернизма, при чем это близость, имеющая источник не во влиянии уже сложившейся программы, но в совпадении, в одновременном ощущении недостатков распрастраненных форм и в стремлении обновить их так, чтобы привлекали внимание современного читателя.

Упомянутую аналогию с постмодернизмом в эстетическом аспекте сигнализируют такие свойства детективной прозы Короткевича, как жанровый синкретизм, заметный прежде всего в нарушении границ между высокой и массовой, развлекательной литературой, а также между поэзией и прозой, кроме того открытая интертекстуальность, проявляющаяся на всех уровнях организации текстов, свободная трактовка границ между фактом и вымыслом, правдоподобием и условными формами, в первую очередь исторической фантастикой, экспериментаторство в языкотворчестве (выбор языка «под эпоху»), дающие о себе знать в оживлении забытых белорусских слов, присутствии неологизмов и архаизмов в описаниях сохранившихся памятников старины и в цитированных песнях, преданиях и легендах. В идеологическом аспекте мировоззренческая самостоятельность автора проявляется в критике разных систем ценностей: христианской (в обоих произведениях заметно, что слуги костела нарушают заветы Христа, что распространилась фальшивая, мнимая набожность, заметная хотя бы в поступках строящего храмы жестокого убийцы Ольшанского), советской идеологии (абсурды, замеченные Космичем, близким автору героем «Черного замка...»), польского и русского влияний на белорусскую историю, оценки роли белорусской аристократии и дворянства в этой истории.

Итак, реалистическое повествование о прошлом, с подробным и убедительным анализом отношений между дворянами и крестьянами, с аксиологической интерпретацией недавнего прошлого, сопровождается развитием детективного, любовного и приключенческого сюжетов (главный герой-рассказчик влюбляется, решая детективную загадку, сам принимает участие в угрожающих его жизни событиях), а также поэтическими описаниями разных явлений. Атмосфера готического романа ужаса (призраки во дворце и в окружающем его про- 
странстве) разоблачается в конце повествования, благодаря научному методу следствия. В поведении главных героев - ученого, этнографа Андрея Белорецкого и юной аристократки Надежды Яновской романтическое уживается с трезвым практицизмом; вообще многие слагаемые романтической парадигмы - метафизическое, таинственное, потустороннее, трагическая любовь, безумие, экзотическая природа, борьба за свободу и т. п., подвергаются переосмыслению с точки зрения мировоззрения, свойственного образованным людям конца XIX столетия, названного «веком пара».

На уровне конструирования больших семантических фигур Короткевичем использованы известные сюжеты и мотивы, напр., из истории филологии (герой ищет в глуши и записывает фольклорные произведения, аналогично как несколько десятилетий раньше братья Гримм в Германии или польские и белорусские романтики в той же Беларуси, напр., Ян Чечот), из рыцарского эпоса (рыцарь, готовый защищать даму сердца), романа плаща и шпаги (дуэли, бегства, погони, засады) авторства Скота, Дюма и Сенкевича, сюжетные ходы Артура Конан Дойля из серии о Шерлоке Холмсе («Собака Баскервилей»), психологической и лирической прозы и т. п.

Можно сказать, что свое дебютантское произведение автор создавал из осколков разных готовых элементов, заимствуя и перемешивая слагаемые многочисленных известных архетипов и образов, используя десятки культурных кодов в коллажной конструкции сюжета, и в не менее коллажной концепции главных и второстепенных героев, картин природы и образа мира, в т. ч. образа Беларуси и белорусов; в произведении найдем «всего понемножку», и именно мозаичность создает эффект нового и интересного художественного явления. Кроме того, в поэтику детективного жанра включено много элементов, ему не свойственных, таких как поэтические описания разных явлений, богатая и многозначная символика, философские размышления, публицистические вставки, научные комментарии к фактам и явлениям истории, что дает основания говорить в этом случае об эстетическом плюрализме и «поэтике избытка» художественных приемов.

Среди героев найдем молодого, но уже достигшего определенных успехов человека революционных взглядов, начитанного 2 , знающего

2 Автор приписал герою «Дикой охоты...» собственные исторические, литературные и житейские знания. Незаурядную эрудированность Короткевича подчеркивают авторы монографий: А. Верабей, Жиъвая повязь часой. Нарыс творчасиі Уладзіміра Караткевіча, Мінск 1985, с. 65; А. Русецкі, Уладзімір Караткевіч: праз гісто- 
прошлое и городскую современность. Именно этот герой выступает в роли рассказчика (и porte parole автора), который вспоминает события почти семидесятилетней давности, воссоздавая их так, как бы они происходили в настоящем или в совсем недавнем прошлом (идеальная память), называя себя «последним свидетелем», рассказывающим «сущую правду»; несколько раз герой-рассказчик обращается к читателю-современнику, жившему во второй половине ХХ столетия, но это в принципе не нивелирует иллюзии реальности создаваемого в повествовании уже исчезнувшего мира.

В Белорецком аналитический ум, знания и житейский опыт уживаются с наивностью, имеющую причины в доверчивости (черта большинства славян) и его собственной честности, и, как уже упоминалось, с чертами рыцаря ${ }^{3}$. Это человек, являющийся продуктом позитивизма, но не потерявший связи с ценностями предшествующей эпохи, (польскому читателю напоминающий Вокульского из «Куклы» Болеслава Пруса), который высоко ценит рыцарский гонор, испытывает сочувствие и любовь к страдающим, в т. ч. к бедным крестьянам. В глухом уголке Беларуси он сталкивается с остатками старого, гибнущего мира - с вымирающим белорусским дворянством, со следами бывшего величия и великолепия, и ему поручена автором роль судьи этого класса.

Поздним романтиком можно назвать бунтующегося против существующих порядков Свециловича с его платонической любовью к Надежде Яновской, готовностью сражаться за свои идеи со всеми сильными мира сего и отдать за них жизнь, что и стало причиной его трагической и романтически красивой, но совершенно ненужной смерти, закончившей историю очередного дворянского рода.

Исключительным типом героя является в повести ее главный женский персонаж, юная аристократка, с которой свел Белорецкого случай или судьба. В ее образе автор также синтезировал ряд слагаемых разных литературных архетипов. Наследница Болотных Елин показана в повести, как и все остальное, через призму восприятия главно-

рыю $і$ сучаснасиь, Мінск 1991, с. 76; А. Мальдзіс, Жьицё $і$ ўзнясенне Уладзіміра Караткевіча, Мінск 1990; Аналогично и прототипом Космича из «Чорнага замка Альшанскага» исследователи считают самого Короткевича - см.: Л. Рублевская, Чорныл лекар, [online], http://sb.by/post/83870 [дата доступа: 14.02.09].

3 А. Воробей относит этого героя к рыцарям Беларуси, что в общем не подвергается сомнению, но рыщарские черты все-таки являются сверх-народными. См.: А. Верабей, Герой прозы Уладзіміра Караткевіча, [в:] Уладзімір Караткевіч $i$ яго творчасць у еўрапейскім культурным аспекце, "Беларусіка". "Albarutheniса" 16 , Мінск 2000 , с. 45. 
го героя-рассказчика, который сперва видел в ней только аристократку, значит существо, принадлежащее своему классу, чужое, странное, некрасивое и несчастное. Читатель знакомится с серией ее портретов, отражающих перемену отношения рассказчика. В первых зарисовках подчеркивается прерафаэлитская прозрачность и легкость ее тела, знаком чего являются просвечивающие жилки на висках, легкая походка, иллюзия, что, танцуя, она плывет в воздухе. Но эти черты не трактуются как носители красоты (эстетика символизма), напротив, они комментируются снижающими определениями «заморыш», «гадкий утенок». Внимательный читатель вспомнит ряд литературных героинь, напр., княжну Болконскую из «Войны и мира», так как герой-рассказчик одновременно с внешней некрасивостью замечает красоту и величие духа девушки, затем - пушкинскую Татьяну, особенно в сцене бала, а в конце повествования - жен декабристов, которые следовали в Сибирь за своими мужьями.

С временем поступки и слова Надежды заставляют Белорецкого увидеть в ней «человека сердца», что дает основания считать понятие «солипсизм сердца» основой романтически-символистской концепции этого персонажа. В комментариях к поведению героини экспонируется, что для нее сердце является инструментом познания, оценки людей, посредником между миром конкретным, индивидуальным и трансцендентным. В тексте многократно подчеркивается, что трагедии и ужасы, которые выпали на ее судьбу: смерть отца, призраки во дворце, «ожившая» легенда, припоминающая о возмездии за преступления предков, нищета крестьян, подлость соседей и дворцовых слуг - ранят ее прямо в сердце, обрекают на одиночество среди людей и заставляют думать о смерти как избавлении в возрасте 18 лет. Девушка готова умереть за грехи предков, еще не начав жить, но все-таки ей жаль умирать, жаль того, чего не видела - солнца, открытого пространства, сытых, счастливых крестьян, и такие желания должны восприниматься как разоблачение романтического апофеоза смерти и шире - романтической концепции героя. Одновременно сердце трактуется автором как место пульсирования эмоций и желаний, в том числе желания жить и любить. Благодаря счастливой любви (возвышенной и нежной, когда влюбленный берет на себя роль надежного опекуна любимой) и разгадке драматических тайн в конце повествования наступает полная метаморфоза Яновской - она возвращается к жизни и порывает со своим сословием, в революционно-советском духе отдает дворец и все его ценности обществу и помогает мужу-революционеру. Надо подчеркнуть, что в 50-е годы, когда создавалась повесть, тезис о существовании пре- 
лестных и добрых аристократок, достойных любви революционеров, звучал довольно провокационно, и в «Черном замке..» сам автор «исправил его», создав портрет никчемного потомка князей Ольшанских.

В повести развита своеобразная концепция красоты и уродливости, наиболее заметная в женских портретах предков Яновских, висящих в зале дворца, в пейзажах, в описаниях дворца и предметов искусства. Эта концепция красоты содержит акценты полемики и с романтической теорией интереса ко всему исключительному, таинственному, мрачному, и с советским снисхождением к внешнему облику человека и пренебрежением ко всему, что создано аристократией. Живописные портреты некрасивых женщин, висящие на стенах дворца, отражают низменные черты их характера, напр., готовность совершить убийство или проклясть потомков.

Внешняя красота Надежды стала заметной, когда исчез убивающий ее страх и вечная грусть, когда она вернулась к жизни. Атрибуты красоты в данном случае - это не классическая симметрия и идеальные пропорции, а симпатичный облик и живость лица, сигнализирующие о богатстве и доброте души человека.

Положительность и красоту главных героев усиливает принцип экспозиции контраста окружения - и внешне и внутренне отвратительных соседей-помещиков, с интриганом-убийцей в овечьей шкуре Дуботовком во главе. И он, и другие дворяне описаны Короткевичем в стиле Николая Гоголя и портретиста Франциско Гойя. Бал в Болотных Елинах трактуется как собрание оживших и вылезших из своих нор духовных мертвецов, карикатур на человеческий род, механических людей-кукол, одетых и ведущих себя по уже вышедшему из моды шаблону. Писатель попеременно эпатирует читателя фрагментами текста - носители прекрасного и возвышенного, чередуются с коллективными и индивидуальными карикатурно-гротескными описаниями второстепенных персонажей:

Я видел замасленные лица, которые галантно улыбались, видел губы, что тянулись к руке хозяйки. Когда они наклонялись, свет падал сверху, и носы казались удивительно длинными, а рты - провалившимися. Они беззвучно расшаркивались, склонялись, бесшумно говорили, потом улыбались и отплывали в сторону, а на их место плыли новые. Это было как в страшном сне. Они оскаливались, будто выходцы из могил, целовали руку (мне казалось, что они сосут из нее кровь) и беззвучно плыли дальше 4 .

4 В. Короткевич, Дикая охота короля Cmaxa, пер. В. Щедрина, http://www. knihi.com. Дальше при ссылке на этот источник в скобках указывается страница. 
Замечание героя насчет крови надо считать предсказанием эскалации ужасного и сенсационного в сюжете, так как большинство гостей это организаторы и участники «дикой охоты», убийцы, притворяющиеся пришельцами из мистического пространства или потустороннего мира, стремящиеся подчинить себе недавно освобожденных от крепостного права крестьян и захватить имение Яновской, а ее самую свести с ума или лишить жизни. Гоголевскую карикатурность белорусского дворянского мира усилит еще сцена пьянства и обжорства в доме Дуботовка, предшествующая «охоте» на мешающего бандитам Белорецкого.

Короткевич местом действия избрал «готический пейзаж» - мало кому теперь известное пространство лесной болотной местности с трясинами, пустошами, прорвами и бездорожьем, с высокими, закрывающими солнце елями, неприятное и для местных жителей, и для приезжих (читаем: это был самый мрачный, самый безнадежный из наших пейзажей: торфянье болота, с. 4). Это территория, где царствуют мрак, влага, туманы, дождь и вечная непогода. В трясинах гибли и гибнут люди, в т. ч. почти триста лет тому назад коварно убивший «крестьянского короля» предок Яновских Роман и совершенно недавно его потомок в «одиннадцатом колене», отец главной героини. Болото поглотит и многих дворян, которые использовали его свойства для материализации легенды о воскресшем короле Стахе и загробной мести для индивидуальных низких целей. Атрибуты пейзажа «Охоты...» - это тучи, закрывающие солнце, а ночью еле-еле выглядывающая из-за них холодная луна, скупо освещающая кроме болота равнодушный ко всему вереск, по которому перемещаются наводящие страх на всю округу всадники «дикой охоты». Многократно в повести используется параллелизм внутреннего состояния человека и природы, человека и вселенной, зависимость человеческой жизни от природных условий; знание этих условий может помочь спасти жизнь (ускользнувший от «охотников» Белорецкий, свободно передвигающийся по кочкам на болоте и незаметным тропинкам крестьянин Рыгор) или стать причиной смерти (погибшие Яновские).

В зарисовках пейзажа и интерьеров Короткевич, вслед за символистами и автором теории света Ньютоном, пользовался световой символикой и оптическими знаниями на тему взаимосвязей света и темноты, реальных очертаний с отсветами и полутенью, расплывшимися или слабо заметными линиями, способными менять реальное и придавать ему черты таинственного и ужасного. На страницах повести упоминаются разные виды и источники света, рассеивающие хотя бы на время 
мрак, естественные и искусственные, напр., луна, огонь в камине, факелы и свечи, дневной свет. Свет или его отсутствие обусловливают индивидуальное восприятие окружающего мира и участвуют в перемене обыкновенного в таинственное и таким образом играют важную роль в конструировании детективного сюжета. Аналогичную роль в создании детективно-мистической атмосферы выполняют также звуковые элементы, например, в темном пустом дворце жителей пугает эхо, многократно усиливающее отголоски шагов по скрипучих досках полов, тревогу наводит доходящее издали пение охотничьего рога, предвещающее приближение «дикой охоты», иногда топот лошадиных копыт и душераздирающий крик, предвещающий чью-то смерть. Световые и звуковые эффекты использованы как приемы поэтизации и ритмизации прозы, что особенно заметно, например, в повторяемых несколько раз описаниях всадников «дикой охоты», Малого человека Болотных Елин, Голубой женщины, а в «Черном замке...»- белой дамы и черного монаха, прогуливающихся по руинах. Вот один из многочисленных примеров, припоминающих атмосферу бестселлеров Толькена:

Со стороны леса по пустошам довольно стремительно двигалась какая-то темная масса... Потом (я) услышал дробный и ровный топот копыт. Шелестел вереск. Затем все исчезло, масса, вероятно, спустилась в какую-то ложбину, а когда появилась снова - топот пропал. Она мчалась бесшумно, словно плывя в воздухе, приближаясь все ближе и ближе... В волнах слабого прозрачного тумана четко вырысовывались силуэты всадников, мчавшихся бешеным галопом, только конские гривы развевались по ветру... Смутные тени всадников бежали от дороги наискось к болотистой ложбине. Развевались по ветру их плащи-велеисы, всадники прямо, как куклы, сидели в седлах, и ни звука не долетало оттуда. Именно в этом молчании и был весь ужас. Какие-то светлые пятна плясали в тумане... Дикий вереск пел под копытами коней... Их кони распростерлись в воздухе, всадники сидели неподвижно, вереск звенел под копытами. И над ними, в лоскутке чистого неба, горела одинокая чистая звезда (c. $45-46)$.

Благодаря наблюдениям и трезвому анализу увиденного и услышанного таинственная «темная масса» превратится в конкретных людей, плывущие в воздухе кони - в редкую породу лошадей, подготовленных к езде по местности; полумрак и своеобразные звуки или мертвая тишина превращают реальное в мистическое, если им сопутствует страх, основанный на многовековых верованиях и суевериях. Свет необходим для разоблачения мистики, вторгающейся в действительность, изображенную по принципу правдоподобия. 
В анализируемом произведении чуть ли не каждая деталь используется в двойной функции - как слагаемое конкретного образа и в обобщающей символической, при чем символы можно наполнять актуализированным смыслом. К емким символам принадлежат, между прочим, болото, «дикая охота», дворец, свет, солнце, мрак и много других. Болото - это символ всего природного, что мешает человеку жить счастливой, то есть, здоровой (крестьяне умирают от болотной лихорадки), сытой и радостной жизнью, символ и общественных условий, сковывающих человеческую энергию; мрак - синоним отсталости, примитивности. Мир вообще разделен в этом произведении на две части - болото и лишь бегло охарактеризованное пространство за его пределами: за болотами тоже нищета и забитость, но люди как-то ищут спасения» и находят его (11). В связи с тем болото можно считать и символом Беларуси, или еще шире - той части земного шара, где царствуют нищета и насилие.

Наиболее емким образом является заглавная «дикая охота»; в этом понятии запечатлено народное убеждение (свойственное многим народам) в том, что никакое злодеяние не пройдет ненаказанным, что справедливость восторжествует, если не на земле, то на том свете, благодаря сверхъестественным силам. Но одновременно «дикая охота» символизирует вечную человеческую подлость, алчность и жестокость, механизм жизни «по закону джунглей», когда сильные ради собственной корысти всякими способами подчиняют себе слабых.

На страницах повести смысл сперва загадочного явления «дикая охота» расшифровывается постепенно, благодаря многократным описаниям охотников и их действий. Информации просачиваются из старинной рукописи и хаотических рассказов жителей дворца, затем из более трезвых наблюдений крестьянина-охотника Рыгора и ученого Белорецкого. В описаниях многие слова повторяются, но каждый раз прибавляются новые детали. Заканчивая пересказ, герой-рассказчик подчеркивает, что и через семьдесят лет после расправы с обманщиками, использовавшими старую легенду, он видит охоту во сне, что превращает ее из явления локального и временного в вечное, универсальное: Я просыпаюсь и думаю, ито не прошло ее время, пока существует мрак, голод, неравноправие и темный ужас на земле. Она символ всего этого. Утопая наполовину в тумане, мчит над мрачной землей дикая охота (97).

Конечно, эти общие определения можно отнести и к «идеальной» советской эпохе, когда создавалась повесть, и к началу XXI века.

Как уже упоминалось, псевдоготический локализированный в про- 
шлом детективный сюжет был использован автором для введения целого ряда очень сложных и до сих пор нерешенных историософских и конкретно исторических проблем, в первую очередь таких, как модель истории Беларуси, история и характеристика дворянства и аристократии на ее территории, история формирования национального сознания и национальной тождественности белорусов, их отношений к полякам, русским и литовцам, к собственному государству. Конкретизацию этих проблем найдем в комментариях и размышлениях героя-рассказчика, а также в высказываниях других героев и в картинах изображенного в произведении мира.

Автор не воссоздает прошлое Беларуси по принципу историзма, но подчиняет его идее «укрепления сердец», аналогично как Генрик Сенкевич $^{5}$ в своей трилогии. Если бы не указанные в тексте даты развития действия и рождения легенды (1601г.), его трудно было бы определить, так как исторические факты в нем почти не упоминаются. В повести появляется лишь мимоходом упоминание о короле Сасе, о Январском восстании (1863-1864), его белорусском герое Кастусе Калиновском ${ }^{6}$ и расправе с участниками восстания. Известная по многим историческим и литературным источникам ситуация в пореформенной Беларуси - части русской империи, в общем показана убедительно (нищета большей части крестьянства) ${ }^{7}$, но некоторые явления явно гиперболизированы, как, например, «массовое вымирание белорусской шляхты». В тексте повести сообщается, что восставший в начале XVII века на борьбу за самостоятельность «крестьянский король» Стах Горский является героем легенды и с подлинной историей никак не связан. Но легенда, напоминающая поэтическую романтическую балладу, отражает вечно актуальные, особенно для восточных славян, мечты о гуманном и умном властелине, и одновременно, по принципу контраста, характеризует исторических царей и королей.

\footnotetext{
5 А. Мальдзіс, Уладзімір Караткевіч - пісьменнік беларускі і еурапейскі, «Беларусіка» 16 , с. 36 .

6 Об образе Калиновкого в пьесе Короткевича Кастусь Калінойскі см.: W. Supa, $W$ kregu dziedzictwa literackiego powstania styczniowego na Białorusi. Dwa dramaty o Konstantym Kalinowskim, "Slavia Orientalis" 1998/2, s. 231.

7 Ср.: Дапаможнік па гісторыі Беларусі для паступаючых у вышэйшыя навучальныля ўстановы, ред. А. Каханоўскі і др., Мінск 1995, с. 150.
} 
Книги по истории Беларуси сообщают о бунтах феодалов не в XVII, а в XVI столетии ${ }^{8}$ и не упоминают о «хромом Яраше Штамете», крестьянском союзнике короля Стаха, не экспонируют значения деятельности Валюжинича из «Черного замка..». Род Ольшанских вымер в половине XVI века. Есть развалины замка в деревне Гошмяны, недалеко от Ошмян и во всей Европе живут многочисленные легенды о найденных в стенах или подвалах разных замков скелетах, о белых и черных дамах или «лысых Брунгильдах», появляющихся в лунные ночи. Как уже упоминалось, исторический фон детективов Короткевича надо назвать очень скромным и не очень точным.

В обсуждаемых произведениях имеем дело одновременно с элементами истории альтернативной (идея окончательного сформирования белорусского самосознания в эпоху Возрождения и ее последовательное развитие на протяжении следующих столетий, живучесть этой идеи) и криптоистории ${ }^{9}$. Но преобладает свободная трактовка фактов и вымысла, и в связи с этим более подходящим, чем «исторический детектив», термином в отношении их можно считать применяемое к появившимся несколько десятилетий позже произведениям Бориса Акунина определение «детектив ретро» 10 .

Игра писателя историческими фактами и вымыслом отражает стремление создать объективную модель истории Беларуси, освобожденной от советских и польских влияний. $\mathrm{K}$ еще не решенным ни польскими, ни белорусскими исследователями проблемам принадлежит функционирование Беларуси в рамках общего государства - Peчи Посполитой и Великого Княжества Литовского, затем размеры полонизации и с конца XVIII века - русификации. С выше названной проблемой связана очередная - существовало ли белорусское дворянство, или только польское, литовское и русское, живущее на территории сегодняшней Беларуси. Понятия, которые употреблял Короткевич - «белорусское дворянство» и «белорусский народ» в прошлом не функционировали, по крайней мере историки не находят убедительных свидетельств, что шляхта живущая на Беларуси называла себя

8 См., напр.: Нарысы гісторыі Беларусі, ред. М. Касцюк, Мінск 1994, ч. 1, с. 159.

9 Криптоистоирия - изображение основанное одновременно на факте и вымысле, который трудно опровергнуть ввиду неполноты доступных нам исторических данных. См.: А. Шмалько, Нечто о сущности криптоистории, [в:] Наша фантастика, Москва 2001, с. 400 и след.

10 Таким термином определяются детективы Бориса Акунина из «фандоринского цикла», в которых связь с историзмом гораздо более заметна, чем в детективах Короткевича. 
белорусской ${ }^{11}$. Понятие народа тоже принадлежит к довольно поздним и в случае восточной Европы оно вошло в обиход в конце XIX - начале XX века ${ }^{12}$, известно также, что во второй половине XVII века наступила на территории Беларуси полонизация аристократии, а также «большой и средней шляхты» 13 .

Но есть и историки, которые защищают тезис о функционировании среди дворянства белорусского национального сознания, например, А. Грыцкевич ${ }^{14}$. Однако другие белорусские историки, например, П. Лойко и О. Латышонок подчеркивают роль польских, литовских и русских элементов в дворянском менталитете и также космополитизм этого сословия.

Короткевич в детективах решает эти проблемы однозначно и уверенно: в его концепции белорусское сознание и язык сохранились и в народе, и в сознании части белорусских дворян, которые вымерли в конце XIX столетия. Но как все слагаемые мира в прозе этого писателя, так и образ Беларуси и дворянства в детективах являются неоднозначными, и даже противоречивыми. Итак, в повести создан образ Беларуси, близкий к традиционному в белорусской литературе XIX и первой половины XX веков, Беларуси «византийской», бедной, грустной и несчастной. В размышлениях рассказчика и в высказываниях главных героев доминируют чувства жалости и сочувствия к родной земле (64) и ее жителям. Это край «номадов», неизмеримых лесов и болот, призраков и привидений, где крестьяне умирают от голода и лихорадки, а дворяне совершают подлые убийства ради власти и денег (преступление предка Яновских в прошлом, Дуботовка и его соратников в романном «настоящем» времени, злодеяния князя Ольшанского), где на каждом шляхетском гербе кровь, грязь и сиротские слезы (17), где вообще сиро и холодно жить человеку, но где в прошлом были герои, борющиеся за свободу и независимость, как король Стах и Валюжинич, где строили великолепные замки и дворцы, создавали предметы искусства, печатали и хранили книги (библиотека, карти-

\footnotetext{
11 Zob.: T. Kruczkowski, H. Wasiuk, Historia Polski czasów WKL i Rzeczypospolitej $w$ białoruskim czasopiśmiennictwie historycznym konca lat 80-tych - poczatku 90-tych XX w., [w:] Polsko-białoruskie zwiazki jezzykowe, literackie, historyczne i kulturowe, red. M. Kondratiuk, Grodno 1999, s. 131.

12 Там же.

13 М. Біч, Дзяржаўнасць Беларусі: станаўленне, страсиі, бараџьба за аднаўленне (IX cm.-1918 е.), "Беларуская мінуўшчына" 1993, № 5-6, с. 6.

14 А. Грыцеквіч, Беларуская шляхта, "Спадчына" 1993, № 1, с. 12.
} 
ны, столовая посуда местного изделия в дворце Яновских), любили и умирали за право любить, как Ганна Ольшанская и Валюжинич, где революционеры-романтики, как реальный Калиновский и вымышленные Свецилович и Белорецкий сражались за лучшее будущее и находили общий язык с крестьянами. В «Черном замке...» по известным причинам (идеология и цензура) образ послевоенной Беларуси получился довольно традиционным, характерным для советского времени - подчеркивается, что виновниками всех бед и несчастий белорусского народа являются немецкие захватчики, а в прошлом продажные феодальные паны.

Короткевич в своей прозе намеренно нарушал стереотип трусливого и покорного беларуса-крестьянина, беларуса, страдающего комлексом неполноценности ${ }^{15}$. В общем, как уже замечалось исследователями, и в детективах показан качественно новый образ Беларуси как земли бедной и терзаемой несчастьями, но с многовековой культурой, передаваемой из поколения в поколение. Кроме этого, Короткевичем создан также новый для белорусской литературы тип героя - ученого интеллектуала ${ }^{16}$, способного по научному объяснить факты в прошлой и текучей жизни и бороться с проблемами, которые она несет, с разными проявлениями зла - именно к таким героям принадлежат Белорецкий из «Дикой охоты...» и Космич из «Черного замка...».

Несмотря на бег времени, детективы Короткевича не потеряли обаятельности благодаря умелому синтезу серьезного, провокационного содержания, занимательной интриги, лиризма и поэзии, актуальности, затрагиваемых в них проблем. Напротив, современное литературоведение дает возможность увидеть и оценить глубину мысли, оригинальность и изысканность их синкретической формы.

\footnotetext{
15 А. Минский, Владимир Короткевич и новый герой белорусской культуры, «Деды» 2012, № 11, с. 307, [online], pawet.net/library/o_philology/200/МинскийАлесь_ Владимир_Короткевич_и_новый_герой_белорусской_культуры.html, [дата доступа: 15 . 10.2015].

16 Ср.: А. Мальдзис, Писатель, время, легенда, http://sb.by/post/34880/.
} 
S T R E S Z C Z E N I E

\title{
POWIEŚCI DETEKTYWISTYCZNE WLADIMIRA KARATKIEWICZA: WCZORAJ I DZIŚ
}

W artykule omówiono problematykę i synkretyczną poetykę dwóch „kryminałów retro" W. Karatkiewicza. Pisarz w dobie dominacji realizmu socjalistycznego połączył w swych utworach ważne idee (kształtowanie świadomości narodowej Białorusinów, interpretacja historii Białorusi) z elementami sensacji i romantycznym wątkiem miłosnym, charakterystycznymi dla modnej dzisiaj kultury masowej, wyprzedzając tym samym swoje czasy.

Słowa kluczowe: historia, powieść sensacyjna, tożsamość narodowa Białorusinów, intertekstualność.

\author{
S U M M A R Y
}

\section{VLADIMIR KARATKIEVICH'S DETECTIVE NOVELS: YESTERDAY AND TODAY}

In the article problems and syncretic poetry in two retro detective novels written by V. Karatkievich are discussed. In the era of dominance of socialist realism the author combined important ideas (defining Belarusians' national awareness, interpreting the history of Belarus) with the elements of sensation and romantic love motif, typical of modern popular culture which are ahead of their time.

Key words: history, detective novel, Belarusians' national identity, intertextuality. 